УДК: 658.1

JEL Classification: M 21

\author{
Н. Й. РАДІОНОВА, \\ кандидат економічних наук, \\ дочент кафедри обліку і аудиту, \\ Київський на́ијінальний університет \\ технологій та дизайну
}

\title{
Систематизація затратоутворюючих факторів для цілей управління затратами виробничого підприємства
}

У статті розглянуто фактори, які впливають на затрати виробничого підприемства. Затратоутворюючі фактори класифіковано за двома категоріями: структурні і функціональні. Проаналізовано зміст структурних та функціональних факторів управління затратами. Показано вплив одного зі структурних факторів на затрати і прибутковість підприємства.

Ключові слова: управління затратами, виробничі затрати, класифікауія затрат, скорочення затрат, підприємство.

Постановка проблеми та ї̈ зв'язок із важливими науковими та практичними завданнями. Важливе значення для аналізу і контролю рівня затрат має виділення і структурування факторів, що визначають їх рівень. Для управління затратами у вітчизняній і зарубіжній літературі і практиці не представлено досить повну і коректну систематизацію факторів впливу на затрати виробничого підприємства. 3 метою більш ефективного управління затратами слід систематизувати затратоутворюючі фактори підприємства.

Аналіз останніх досліджень і публікацій. Загальні питання управління затратами підприсмства знайшли висвітлення у працях вітчизняних та зарубіжних науковцівекономістів - Т. Адаменко [1], Ю. Гавриленко та А. Коваль [2], Т. Гринько та К. Столпової [3], Н. Костецької [4], Н. Хаймьонової [5], Т. Яровенко [6], А. Ясінської [7] та інших.

Вітчизняні та зарубіжні автори зробили значний внесок у вирішення проблем, що розглядаються в статті, проте не вичерпали їх. Широке коло питань теоретикометодологічного, прикладного характеру, пов'язаних із визначенням та систематизацією затратоутворюючих факторів для більш ефективного управління не отримало досить повного й однозначного вирішення і потребує подальшого дослідження.

Метою дослідження є виділення і структурування факторів, що впливають на затрати підприємства.

Виклад основного матеріалу дослідження. Поточне управління затратами грунтується на класифікації затрат, побудованої як функція одного визначального фактора - обсягу виробленої продукції. Цим обумовлюється групування затрат на постійні і змінні, середні і граничні, використання методу зіставлення середніх затрат із граничними, аналіз співвідношення затрат, обсягу і прибутку, визначення критичного (беззбиткового) обсягу виробництва, формування гнучких бюджетів, в яких планові затрати відкориговані на фактичні обсяги продукції, аналіз маржинального прибутку. Зазначена класифікація затрат основана на моделях мікроекономіки.

На величину затрат впливають різні фактори, які можна об'єднати в дві групи:

зовнішні фактори, що відображають загальний рівень розвитку економіки країни і не залежать від діяльності суб'єкта господарювання. Вплив цієї групи факторів проявляється в рівні цін на сировину, матеріали, обладнання, енергоносії, в тарифах на воду, паливо та інші матеріальні послуги, в ставках орендної плати, в нормах амортизаційних відрахувань, обов'язкових відрахувань в позабюджетні фонди, в системі оподаткування підприємств;

2) внутрішні фактори, безпосередньо пов'язані з діяльністю суб'єкта господарювання, з його підприємницькою активністю. До них належать: обсяг виробництва i

Н. Й. Радіонова, 2017 
реалізації продукції, форми і системи оплати праці, підвищення продуктивності праці, поліпшення використання основних виробничих засобів, оборотних активів, матеріальних ресурсів, впровадження нових технологій [2].

Для цілей управління затратами пропонується розділити все затратоутворюючі фактори на дві категорії: структурні і функціональні. 3 точки зору структурних факторів для підприємств існує п'ять варіантів для вибору пов'язаних зі структурою затрат для будь-якої групи продукції (рис. 1).

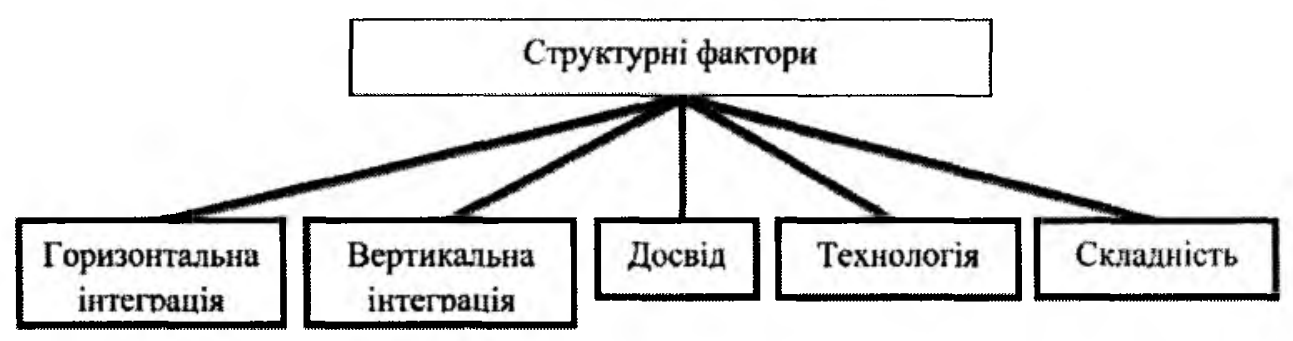

\section{Рис. 1. Структурні затратоутворюючі фактори управління затратами}

Джерело: побудовано автором

Фактор масштабу характеризує обсяг інвестицій для здійснення досліджень i розробок, виробничої, маркетингової та іншої діяльності, необхідної для створення і реалізації продукції. Багато в чому з фактором масштабу пов'язана горизонтальна інтеграція. Ступінь вертикальної інтеграції характеризуеться фактором діапазону. Фактор досвіду показує, скільки разів у минулому підприємство вже робило те, що воно робить і зараз. Технологія відображає технологічні процеси, які використовуються на кожній стадії ланцюжка затрат підприемства. I, нарешті, складність - це показник, що характеризує асортиментний набір виробів [1].

Кожен структурний фактор впливає на вибір, який робить керівництво підприємства в частині управління витратами. Зарубіжна і вітчизняна практика приділяє основну увагу таким факторам як інтеграція і досвід.

Друга категорія затратоутворюючих факторів - функціональні фактори, тобто фактори, що управляють затратами підприємства і визначають здатність підприємства успішно функціонувати [4]. На відміну від структурних факторів, які не мають пропорційної залежності з показниками діяльності підприємства, функціональні фактори прямо впливають на них:

Це означає, що для кожного зі структурних факторів "більше" не означає "краще" (наприклад, якщо масштаб виробництва або діапазон виробленої продукції змінюється в певному напрямку, це необов'язково означатиме, що в такому ж напрямку зміниться i ефективність затрат). Навпаки, для кожного $з$ функціональних факторів “більше" завжди означае "краще" [3].

До функціональних факторів належать (рис. 2):

- мотивація і відповідальність за результати праці; передбачає розроблення концепції мотивації працівників до результатів праці, відповідальності менеджерів за результати діяльності, взяття зобов'язань щодо постійного.удосконалення виробничих процесів;

- стимулювання досягнень, пов'язаних з якістю продукції; потребує створення системи комплексного управління якістю (Total quality management, TQM) шляхом стимулювання досягнень, пов'язаних з якістю продукції і виробничих процесів;

- оптимальне використання виробничих потужностей; передбачає вибір з наявних альтернатив на підставі технологічних характеристик;

- ефективне планування діяльності підприємства, порівняння планових показників 3 нормами - найважливіший елемент функціональної структури;

- фактор конфігурації; відображає ефективність конкретного проекту або розрахунку (бізнес-плану); 
- використання зв'язків із постачальниками і замовниками продукції в контексті ланцюжка затрат підприємства - це один з вирішальних затратоутворюючих факторів [5].

В цілому функціональні фактори $\epsilon$ більш впливовими, ніж структурні.

Дія кожного $з$ вищезгаданих структурних і функціональних факторів спричиняе різні за ступенем важливості наслідки для управління затратами.

Управління затратами означає складну взаємодію сукупності затратоутворюючих факторів у кожній конкретній ситуації. Кожен фактор передбачає можливість вибору для підприємства (наприклад, організація крупносерійного або дрібносерійного виробництва), і цей вибір визначає рівень і динаміку затрат [6]. Для того, щоб зробити правильний вибір, необхідно точно розрахувати затрати, враховуючи кожний фактор.

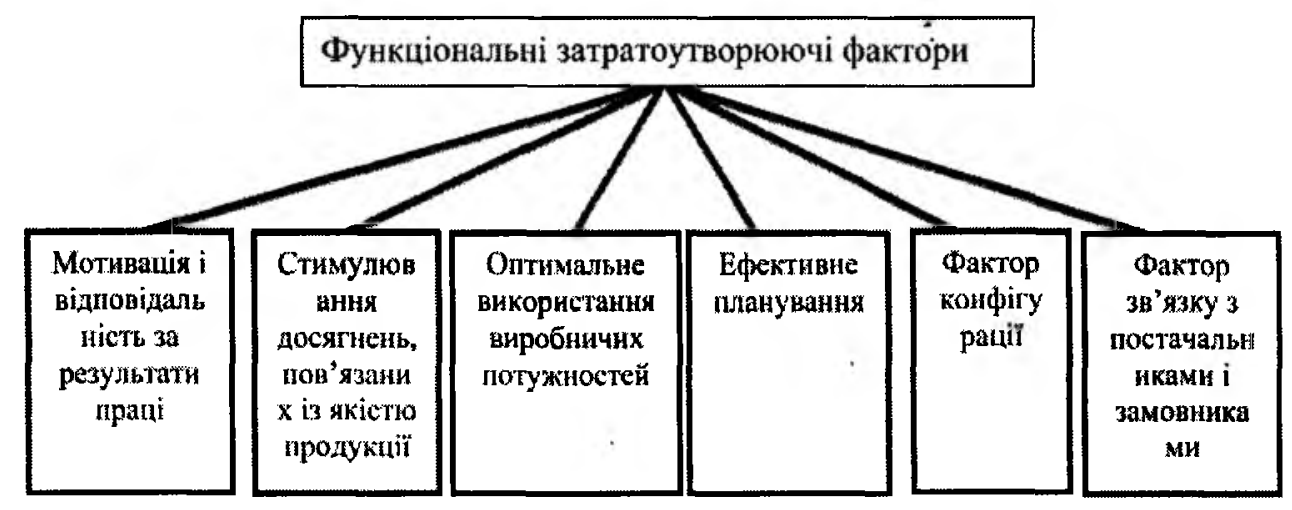

Рис. 2. Функціональні затратоутворюючі фактори управління затратами

Джерело: побудовано автором

Розглянемо, наприклад, вплив одного зі структурних факторів - асортименту продукції (складності), який враховує затрати на основі видів діяльності.

Як правило, підприємство формує пропозицію декількох продуктів (наприклад, $\mathrm{A}, \mathrm{B}, \mathrm{C})$ у вигляді сдиного блоку з чітко визначеною реалізацією таким чином, що ї рентабельність всередині цього блоку різко відрізняється. В такому випадку менш рентабельний (або навіть збитковий) сегмент зазвичай використовується свідомо, як спосіб проникнення на ринок. Затрати виробництва індивідуального продукту не настільки важливі, як загальна рентабельність усього блоку.

Управління затратами 3 метою вибору компромісного рішення між збереженням сегмента ринку шляхом виробництва складного асортименту продукції і рівнем рентабельності на виробництво комплексної продукції вимагає уважного підходу до оцінювання затрат на кожний виріб і блок у цілому. Розглянемо невеликий приклад.

Підприємство виробляє і реалізує на ринку три види виробів (А, В і С) за таких умов (табл. 1):

Таблиия 1

Характеристика реалізації товарів А, В і С на ринку

\begin{tabular}{|l|c|c|c|c|}
\hline \multirow{2}{*}{ Показники } & \multicolumn{3}{|c|}{ Вироби } & Сума \\
\cline { 2 - 5 } & $\mathbf{A}$ & $\mathbf{B}$ & $\mathbf{C}$ & \\
\hline Кількість проданих виробів, од. & 100 & 200 & 400 & - \\
\hline Сумарні змінні затрати, у. о. & 300 & 1000 & 2400 & 3700 \\
\hline Сумарні постійні затрати, у. о. & 600 & 2000 & 4800 & 7400 \\
\hline Загальні сумарні затрати, у. о. & 900 & 3000 & 7200 & 11100 \\
\hline Виручка від реалізації продукції, у. о. & 1200 & 3600 & 6400 & 11200 \\
\hline Рентабельність продукції,\% & 25 & 16.67 & - & 0.9 \\
\hline
\end{tabular}

Джерело: розроблено і побудовано автором, дані умовні 
3 огляду на збитковість виробництва виробу С фірма прийняла рішення змінити асортиментну політику. Оскільки попит на вироби А і В практично насичений, було вирішено виробляти ці вироби в колишній кількості і продавати їх за тією ж ціною. За інших рівних умов зміни в асортименті могли привести до таких результатів (табл. 2):

Табличя 2

Характеристика реалізації товарів А, В і С на ринку за умов зміни асортименту

\begin{tabular}{|l|c|c|c|}
\hline \multirow{2}{*}{ Показники } & \multicolumn{2}{|c|}{ Вироби } & \multirow{2}{*}{ Сума } \\
\cline { 2 - 3 } & А & В & \\
\hline Кількість проданих виробів, од. & 100 & 200 & - \\
\hline Сумарні змінні затрати, у. о. & 300 & 1000 & 1300 \\
\hline Сумарні постійні затрати, у. о. & 1700 & 5700 & 7400 \\
\hline Загальні сумарні затрати, у. о. & 2000 & 6700 & 8700 \\
\hline Виручка від реалізації продукції, у. о. & 1200 & 3600 & 4800 \\
\hline Рентабельність продукції, \% & 8.3 & збиток & збиток \\
\hline
\end{tabular}

Джерело: розроблено і побудовано автором, дані умовні

Таким чином, сподівання підприємства на підвищення середньої рентабельності продажів шляхом вилучення з асортименту виробів збиткового продукту С зі стратегічного погляду виявилося невірним. Воно призвело до того, що через незмінність постійних затрат збитковим стала реалізація виробу В і діяльність підприємства в цілому. Отже, якщо підприємство змінюе асортимент продукції, позбавляючись від очевидно низькоприбуткових продуктів, сумарна рентабельність може знизитися. В такому випадку показники прибутку (i рентабельності) на готову продукцію підприємства не відображають той факт, що стандартна продукція з високим обсягом випуску є набагато більш прибутковою, ніж відображено в калькуляції. I навпаки, дрібносерійна продукція має більш низькі показники прибутку. При такому підході підприємство не може ефективно вирішувати проблеми підвищення конкурентоспроможності, оскільки воно використовує недостовірну інформацію про рентабельність продукції. Щоб застосувати життєздатну стратегію, підприємство повинно володіти методами управління затратами, сформованими за видами продукції.

В останні роки серйозна увага стала приділятися фактору складності в посднанні із системами аналізу затрат і новими інструментами аналізу - методу $\mathrm{ABC}$ i методу XYZ.

При використанні методу АВС, що також має назву “вісімдесят на двадцять", у сукупних затратах на виробництво продукції виділяють той вид ресурсів, затрати на який становлять $80 \%$ вартості ресурсів і формують $20 \%$ найбільш дорогої продукції, і відносять цей ресурс до групи А. До групи В відносять третину ресурсів, затрати на які складають $15 \%$ вартості всіх ресурсів, а на групу С залишаєеться половина ресурсів, питома вага яких у загальних затратах становить лише $5 \%$. Починати управління затратами слід з найменшої і найдорожчої групи продукції - групи А [7].

Метод АВС дуже широко використовується великими вітчизняними підприсмствами. Однак найбільший ефект дас застосування цього методу в комбінації 3 менш відомим методом XYZ (рис. 3). XYZ-аналіз дозволяс класифікувати ресурси в залежності від характеру їх споживання і точності прогнозування змін в їх потребі. 




Рис. 3. Структура затрат з урахуванням створення цінності

Джерело: побудовано автором

Існують три проблеми, вирішення яких дозволяє концепції $\mathrm{ABC}$ вписатися в стратегічно пов'язану з нею систему управління затратами. Ці рішення полягають в наступному.

По-перше, слід забезпечити динамічний погляд на затрати на виробництво продукції, тобто акцентувати увагу при розподілі поточних виробничих затрат на скорочення або навіть зведення до нуля всіх витрат, які не належать до новостворюваної вартості в ланцюжку цінностей. 3 цією метою на додаток до розподілу поточних видів діяльності на виробництво продукції система управління затратами повинна забезпечувати як постійний перегляд тих видів діяльності, які дійсно додають цінність для споживача, так і здійснення цих видів діяльності з максимальною ефективністю.

Тільки види діяльності і відповідні ї затрати в квадраті А повинні бути розподілені на продукцію. Види діяльності в квадраті В повинні бути розглянуті з точки зору шляхів підвищення їх ефективності i, в кінцевому підсумку, перенесені в квадрат А. Види діяльності в квадраті С повинні бути зведені до нуля. Додатково необхідно досліджувати можливості передання ресурсів, що використовувались для видів діяльності в квадраті С, на ті види діяльності, які виробляють ефективну продукцію.

По-друге, оскільки на більшості виробничих підприємств істотна частина затрат на виробництво стратегічного характеру вже була проведена задовго до того, як продукт надходить у стадію виробництва (наприклад, затрати на дослідження і розробки), або ж буде проведена через довгий час після виходу з виробничого процесу (наприклад, затрати на маркетинг і збут), система ABC, що застосовуеться в стратегічному управлінні, повинна повною мірою враховувати ці компоненти затрат. Тим самим ще раз підкреслюеться положення, що стратегічне управління затратами повинно розглядати затрати в широкому сенсі слова, незалежно від того, наскільки точно оцінені затрати у виробничому сегменті ланцюжка цінностей.

По-третє, навіть якщо враховувати і вирішувати обидві розглянуті проблеми, слід мати на увазі, що система АВС пов'язана з розробленням стратегій сьогоднішнього дня. Застосування такої системи управління затратами є небезпечним, якщо вона поширюється на наступні періоди. Тому, застосовуючи метод АВC, необхідно враховувати, що управління затратами включає постійну переоцінку сьогоднішнього конкурентного позиціонування на користь альтернативних варіантів, які в більшій мірі адаптовані до поточного сприйняття майбутньої конкурентної ситуації. Досить часто це вимагає великих коштів і. зусиль підприємства, спрямованих на модернізацію всієї системи управління затратами. 
Важливу роль в управлінні затратами відіграє інший структурний фактор затрат - вибір технології. Ця проблема дуже актуальна для вітчизняної промисловості, де багато підприємств відстають на глобальних ринках через те, що занадто повільно впроваджують нові технології виробництва. Можна розглядати різні причини такого становища, але важливіше досліджувати взасмозв'язок між аналізом капітальних вкладень в нові технології і стратегічним управлінням затратами.

При інвестиціях в науково-технічний прогрес слід керуватися не тільки аналізом ланцюжка цінностей та стратегічним позиціонуванням, а й насамперед аналізом затратоутворюючих факторів, оскільки технологія є істотним фактором затрат на критичних етапах ланцюжка.

3 точки зору бізнесу науково-технічний прогрес мас значення тільки в тій мірі, в якій він впливає на конкурентні переваги або структуру вироб́ництва. Однак технології, що проникають у ланцюжок цінностей підприємства, не обмежуються тими, які безпосередньо пов'язані з виробництвом продукції. Тому будь-який вид технології $€$ важливим для конкуренції, якщо він має значний вплив на конкурентні переваги підприємства. Основним інструментом для розуміння ролі технології в досягненні конкурентних переваг є ланцюжок цінностей. Технологія використовується в кожному виді діяльності підприємства зі створення вартостей, і науково-технічний прогрес може впливати на конкуренцію шляхом впливу на будь-який вид діяльності. Технології в різних видах діяльності можуть бути пов'язані, і це є головним джерелом конкурентних переваг. Більше того, технології підприємства взаємозалежні з технологіями постачальників і покупців. Завдяки цьому. технологія має потужний вплив на затрати підприемства і на процес диверсифікації.

Висновки. Аналіз затратоутворюючих факторів дозволяє зробити такі висновки:

- для поточного управління затратами, в тому числі на базі операційного аналізу, найбільш істотним фактором, що визначає рівень затрат, є обсяг продукції;

- в стратегічному плані підприємству важливіше сформувати затрати стосовно тих структурних альтернатив, які сформують його конкурентоспроможну позицію;

- для цілей управління затратами слід розділити всі затратоутворюючі фактори на дві категорії: структурні і функціональні;

- для кожного фактора затрат існує конкретна система управління, яка має важливе значення для позиціонування підприємства.

\section{Список використаних джерел}

1. Адаменко Т. М. Особливості стратегічного управління затратами підприємства // Економіка. Менеджмент. Підприємництво. 2011. № 23(II). С. 100-106.

2. Гавриленко Ю. М., Коваль А. А. Особливості управління витратами на підприємстві [Електронний ресурc]. URL: http://knutd.com.ua/publications/pdf/ TD/2012-4/12gymvnp.pdf

3. Гринько Т. В., Столпова К. В. Обгрунтування стратегї̈ зниження затрат підприємства [Електронний pecypc]. URL: http://www.zgia.zp.ua/gazeta/evzdia_6_131.pdf

4. Костецька Н. I. Методичні аспекти формування стратегії зниження витрат підприємства // Економіка: проблеми теорії та практики. Дніпропетровськ: ДНУ, 2010. C. 443-450.

5. Хаймьонова Н. С., Головацька С. І. Методичний інструментарій бюджетування у системі управління витратами підприємства // Вісник Львівської комерційної академії. Сер.: Економічна. 2015. Вип. 47. С. 42-46.

6. Яровенко Т. С., Довга А. О., Остряніна В. Е. Шляхи та методи оптимізації витрат підприємства у ринкових умовах // Вісник Дніпропетровського університету. Сер.: Економіка. 2013. Т. 21. Вип. 7(2). С. 181-188.

7. Ясінська А. І. Сутність управління витратами на вітчизняних підприємствах [Електронний ресурс]//Національний університет "Львівська політехніка". 2007. URL: http://vlp.com.ua/files/54.pdf. 
Н. И. РАДИОНОВА

кандидат экономических наук, дочент кафедры учета и судита, Киевский национальный университет - технологий и дизайна

\section{Систематизация затратообразующих факторов для целей управления затратами производственного предприятия}

B статье рассмотрены факторы, влияющие на затраты производственного предприятия. Затратообразуюице факторы классифичированы по двум категориям: структурные и функциональные. Проанализировано содержание структурных и функииональных факторов управления затратами. Показано влияние одного из структурных факторов на затраты и прибыльность предприятия.

Ключевые слова: управление затратами, производственные затраты, классификачия затрат, сокрачение затрат, предприятие.

N. Y. RADIONOVA,

PhD (Economics), Associate Professor of Accounting and Audit Department, Kyiv National University for Technology and Design

\section{Systematization of Cost Factors for Cost Management at Industrial Enterprises}

Identification and structuring of factors determining the cost level has significant importance in cost analysis and control. Cost factors need to be systematized for more effective cost management. The objective of the study is to identify and structure the factors with impact on the enterprise costs. The external and internal factors with impact on the enterprise costs in industry are highlighted. For cost management purposes, it is proposed to group the cost factors into the two categories: structural and functional. The essence of structural and functional factors is shown; a classification of functional factors is given. The effect of a structural factor such as products range (complexity) is illustrated. As the factor of complexity, combined with cost analysis systems and innovative tools of analysis ( $A B C$ and XYZ methods), has been increasingly in focus of analysts, three problems are described which, once dealt with, will enable ABC method to fit into the cost management system. The importance of another structural factor of costs, technology selection, in cost management is shown.

The analysis allows for the following conclusions: for purposes of current cost management, including one based on operational analysis, the output needs to be addressed as the central factor determining the cost level; in the strategic perspective, an enterprise needs to concentrate on calculating the costs for the structural alternatives that are supposed to determine its competitive position; for cost management purposes, the cost factors should be broken into two categories, structural and functional; a specific management system exists for each cost factor, which is greatly important for the positioning of an enterprise.

Keywords: cost management, production costs, cost classification, cost reduction, enterprise.

\section{Посилання на статтю:}

Радіонова Н. Й. Систематизація затратоутворюючих факторів для цілей управління затратами виробничого підприємства // Науковий вісник Національної академії статистики, обліку та аудиту: зб. наук. пр.. 2017. №4. С. 64-70. 